\title{
IMPLEMENTASI PRINSIP-PRINSIP MANAJEMEN PENDIDIKAN ISLAM DALAM HOMESCHOOLING DI TENGAH PANDEMI COVID-19
}

\author{
Sri Ismiani \\ IPB Dramaga, bogor, indonesia \\ Email : Sriismiani593@yahoo.co.id
}

\begin{abstract}
Abstraksi
Dilema para pendidik dan peserta didik saat munculnya pandemi COVID-19, antara sekolah atau diliburkan sampai waktu yang tidak bisa ditentukan. Kementrian Pendidikan dan Kebudayaan menetapkan peraturan untuk melakukan proses belajar mengajar secara daring agar proses pembelajaran tetap berlangsung. Proses belajar secara daring tak selamanya bisa menjadi solusi terbaik di masa pandemi, karena banyak siswa yang memiliki keterbatasan jaringan internet untuk melakukan proses belajar. Homeschooling merupakan salah satu alternatif agar siswa tetap bisa belajar di tengah pandemi. Homeschooling tunggal merupakan salah satu pendidikan non formal yang dilaksanakan oleh orang tua dalam satu keluarga tanpa bergabung dengan lainnya dengan mendatangkan guru ke rumah disaat masa pandemi ini. Dalam keberlanjutan homeschooling dibutuhkan manajemen pendidika yang tepat agar proses pembelajaran berjalan dengan baik. Manajemen pendidikan merupakan implementasi prinsipprinsip manajemen dalam ranah pendidikan. Artikel ini bertujuan untuk membahas implementasi prinsip-prinsip manajemen pendidikan islam dalam homeschooling di tengah pnsemi COVID-19.
\end{abstract}

Kata Kunci: Homeschooling, manajemen pendidikan, Pandemi COVID-19.

\section{Pendahulun}

Laju penyebaran virus Corona sangat cepat dan semakin meluas hingga ke wilayah yang jauh dari pusat wabah berasal. Melihat kondisi tersebut World Health Organization (WHO) sejak tanggal 11 Maret 2020 menetapkan bahwa COVID-19 atau virus Corona (SARS CoV-2) menjadi pandemi global. Dalam waktu kurang dari 3 bulan sejak kasus infeksi pertama teridentifikasi, infeksi corona menyebar ke 200 Negara. Pada tanggal 18 Mei 2020, secara global ada 4.857.311 kasus yang dikonfirmasi dan setidaknya 318.419 kematian karena COVID-19. ${ }^{1}$ Kasus infeksi virus corona juga menyebar ke NTB, dimana kasus pertama positif terinfeksi virus Corona di Lombok dilaporkan pada tanggal 24 Maret 2020. ${ }^{2}$ Penyebaran virus Corona melalui droplets dari saluran pernapasan penderita COVID-19. Virus Corona mampu bertahan pada permukaan benda dan memungkinkan terjadinya penyebaran melalui permukaan benda yang terkontaminasi virus Corona. ${ }^{3}$ Untuk mengurangi dan mencegah penyebaran virus Corona semakin luas maka beberapa upaya dilakukan salah satunya adalah stay at home,

\footnotetext{
${ }^{1}$ úllker Devrim, Nuri Bayram, "Infection Control Practices in Children During Covid-19 Pandemic: Differences From Adults, "Ajic: American Journal of Infection Control, (2020), doi: https://doi.org/10.1016/j.ajic.2020.05.022

${ }^{2}$ https://amp.kompas.com/regional/read/2020/03/24/15035821/update-kasus-pertama-1-warga-ntb-positifcovid-19 diakses pada. Sabtu 4 juli 2020

3úllker Devrim, Nuri Bayram, ibid.
} 
Jurnal At Tadbir STAI Darul Kamal NW Kembang kerang NTB

Volume 5 No 1 Tahun 2021

P-ISSN : 2580-3433

E-ISSN : 2715-7210

https://journal.staidk.ac.id/index.php/tadbir

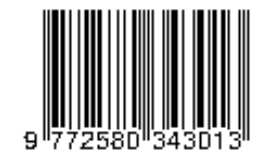

dengan diam di rumah diketahui dapat menurunkan laju infeksi virus Corona. ${ }^{4}$ Kementrian Kesehatan Republik Indonesia mengeluarkan peraturan nomor 9 tahun 2020 tentang pedoman Pembatasan Sosial Berskala Besar (PSBB) sebagai upaya percepatan penanganan COVID-19 yang ditetapkan di Jakarta 31 Maret 2020 oleh presiden Joko Widodo. ${ }^{5}$

Pembatasan sosial bersekala besar meliputi peliburan sekolah hingga waktu yang tidak dapat ditentukan. Sejak tanggal 16 Maret 2020 NTB menghentikan aktivitas sekolah hingga waktu yang tak dapat di tentukan. Untuk memenuhi hak peserta didik agar mendapatkan pelayanan pendidikan selama darurat COVID-19. Kementrian pendidikan dan kebudayaan (kemendikbud) menerbitkan surat edaran nomor 15 tahun 2020 tentang pedoman penyelenggaraan Belajar Dari Rumah (BDR) dalam masa darurat penyebaran virus Corona. ${ }^{6}$ Berdasarkan surat edaran tersebut, saat pandemi COVID-19 proses pembelajaran berubah menjadi model pembelajaran jarak jauh yang menuntut pemanfaatan teknologi informasi sebagai wadah dalam menunjang berlangsungnya peroses belajar mengajar.

Pemanfaatan teknologi informasi merupakan hal baru bagi beberapa sekolah di daerah. Oleh karena itu, dunia pendidikan harus menanggung beban ketidak berdayaan saat berhadapan dengan keterbatasan kemampuan para siswa dan guru karena belum terlatih menggunakan sistem pembelajaran model jarak jauh. Belajara model jarak jauh (Daring) sangat membebankan siswa, karena hanya beberapa siswa yang mampu mengikuti kegiatan belajar secara daring. Pada kenyataanya banyak siswa yang tidak bisa mengikuti pelajaran secara daring karna beberapa faktor : kemampuan menggunakan komputer/ Hp dan kuota internet, tidak semua siswa mampu membeli kuota internet karena penghasilan orang tua yang di bawah rata-rata. ${ }^{7}$ Fakta lain bahwa di luar sana masih ada daerah yang belum tersentuh dengan koneksi internet yang memadai untuk melangsungkan kegiatan belajar jarak jauh. ${ }^{8}$ Oleh karena itu, untuk mendorong berlangsungnya proses belajar mengajar di tengah pandemi COVID-19 diperlukan alternatif pengganti pembelajaran jarak jauh dengan homeschooling. Homeschooling merupakan salah satu alternatif yang sangat efisien untuk tetap melanjutkan proses belajar- mengajar ditengah wabah pandemi COVID-19. Dari uraian diatas, maka penulis bertujuan untuk mengkaji implementasi prinsip-prinsip manajemen pendidikan islam dalam homeschooling di tengah pandemi COVID-19.

\section{Kajian Pustaka}

\section{Pandemi COVID-19}

\footnotetext{
${ }^{4}$ Renan C. Castillo et al, "The Effect of State-Level Stay-At-Home Orders on Covid-19 Infection Rates, "AJIC: American Journal ofinfection Control, (2020), doi: https://doi.org/10.1016/j.ajic.2020.05.017

${ }^{5}$ https://www.jogloabang.com/kesehatan/pp-21-2020-pembatasan-sosial-berskala-besar-rangka-percepatanpenanganan-covid-19 diakses pada. Sabtu 4 juli 2020

${ }^{6}$ https://prfmnews.pikiran-rakyat.com/nasional/pr-13391242/kemendikbud-terbitkan-pedoman-belajar-darirumah-di-masa-darurat-covid-19. Sabtu 4 juli 2020

${ }^{7}$ Siti Aminah, hasil wawancara virtual MTs. An-nasriyah. Kedatu lombok timur, 4 juli 2020

${ }^{8}$ Soalihin, hasil wawancara virtual SMPN 1 Lamboya Barat, Kedatuk Lombok Timur, 1 juli 2020
} 
Jurnal At Tadbir STAI Darul Kamal NW Kembang kerang NTB

Volume 5 No 1 Tahun 2021

P-ISSN : 2580-3433

E-ISSN : 2715-7210

https://journal.staidk.ac.id/index.php/tadbir

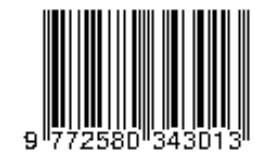

Pada bulan Desember 2019, sejumlah pasien diidentifikasi pneumonia dengan etiologi yang tidak diketahui di kota Wuhan, provinsi Hubei di Cina. Setelah dilakukan penelitian

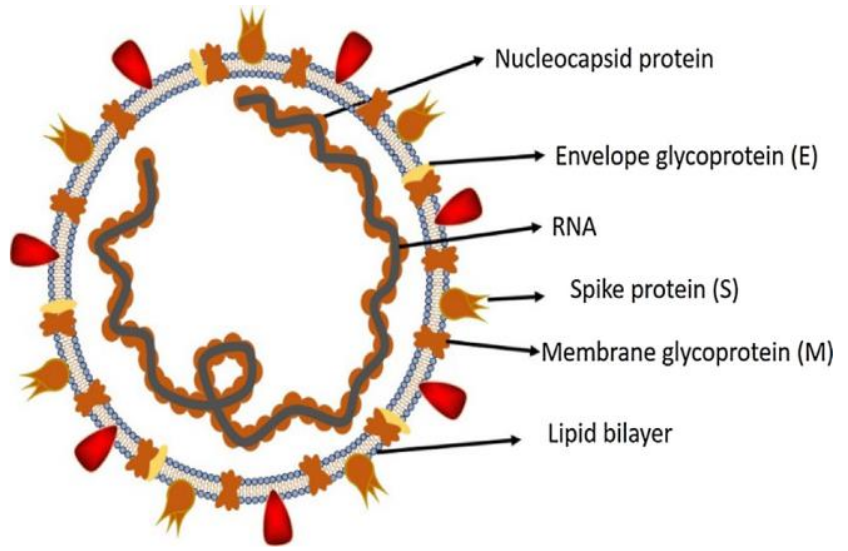

terdapat tipe virus Corona baru diisolasi oleh Chenese Authorities pada tanggal 7 Januari 2020. Internasiolan Komite Taksonomi Virus (ICTV) menemukan virus itu sebagai SARS-CoV-2 dan penyakitnya dinamakan COVID-19. Jadi COVID-19 merupakan penyakit menular yang disebabkan oleh Severe Acute Respiratory Syndrome Coronavirus 2 (SARS-CoV-2) yang merupakan virus Corona jenis baru. ${ }^{9}$ Virus Corona termasuk dalam famili Coronaviridae dan ordo Nidovirales yang memiliki ukuran sangat kecil $(60-140 \mathrm{~nm})$ berbentuk seperti mahkota di bawah mikroskop elektron, serta mengandung RNA untai tunggal sebagai bahan nukleat, struktur virus Corona dapat dilihat pada Gambar $1 .^{10}$

Gambar 1. Struktur respirasi sindrom virus Corona yang menginfeksi manusia (Muhammad adnan shereen et al. 2020).

Siklus hidup SARS-CoV-2 dalam sel inang dapat di liat pada gambar 2. SARS-CoV-2 memulai siklus hidupnya ketika protein $\mathrm{S}$ berikatan dengan reseptor seluler ACE2 (angiotensinconverting enzyme). Setelah pengikatan reseptor, konformasi protein $\mathrm{S}$ berubah memfasilitasi fusi antara permukaan virus dengan membran sel melalui jalur endosom. Kemudian SARSCoV-2 melepaskan RNA ke dalam sel inang. Genom RNA diterjemahkan ke dalam replikasi virus poliprotein ppla dan $1 \mathrm{ab}$, yang kemudian dibelah menjadi produk kecil oleh proteinase virus. Polimerase menghasilkan serangkaian subgenomik mRNA dengan transkripsi diskontinyu dan akhirnya diterjemahkan menjadi protein virus yang sama. Protein virus dan RNA genom kemudian dirakit menjadi virion di retikulum endoplasma (ER) dan Golgi lalu diangkut melalui vesikel dan dilepaskan keluar sel. ${ }^{11}$

\footnotetext{
${ }^{9}$ Muhammad adnan shereen et al, "Covid-19 infection: origin, transmission, and characteristics of human coronavirus, Journal of advanced research, no 24 (2020), 91-98

10 Ibid

${ }^{11}$ Ibid
} 


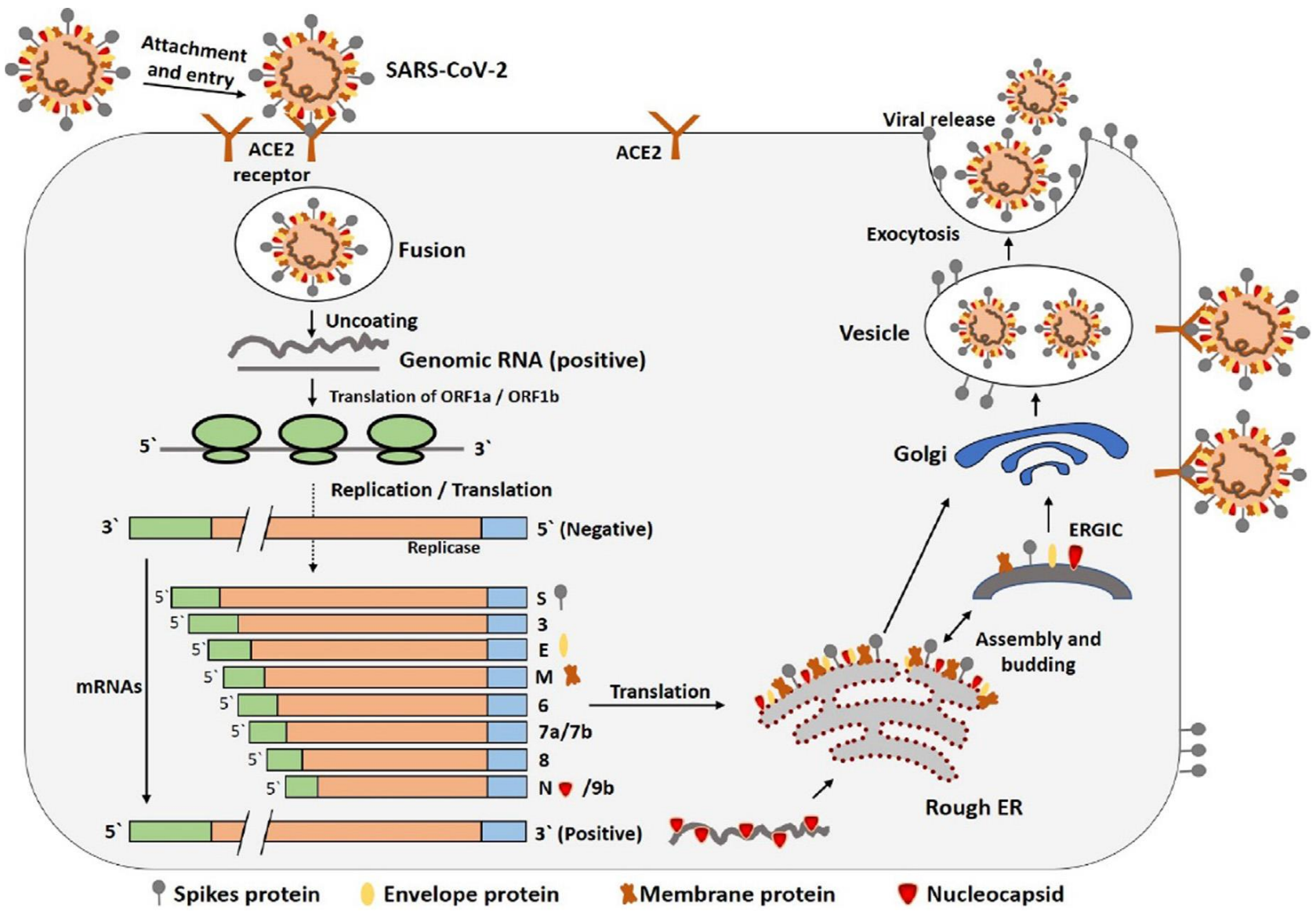

Gambar 2 Siklus hidup SARS-CoV-2 (Muhammad adnan shereen et al. 2020).

Bagaimana cara virus Corona menginfeksi manusia ?. Virus Corona yang dapat menginfeksi manusia yaitu $\alpha$ dan $\beta$ ( Gambar 3). Konsumsi hewan yang terinfeksi sebagai sumber makanan adalah penyebab utama penularan virus ke manusia. Kelelawar Rhinolophus ditemukan memiliki antibodi anti-SARS-CoV yang menjunjukkan kelelawar sebagai sumber replikasi atau tranfer virus. Orang terinfeksi ditularkan ke orang sehat. ${ }^{12}$ Manusia ke manusia menyebar virus terjadi melalui tiga jalur transmisi COVID-19: 1. transmisi aerosol, 2. transmisi tetesan, dan 3. transmisi kontak. Studi terhadap sejumlah besar pasien yang terinfeksi menemukan rute transmisi utama SARS-CoV-2 adalah kontak orang ke orang. Kontak dekat dengan orang yang terinfeksi, terkena batuk, bersin, tetesan pernapasan atau aerosol. Aerosol ini dapat menembus tubuh manusia (paru-paru) via inhalasi melalui hidung atau mulut. ${ }^{13}$

\footnotetext{
12 Ibid, 93.

${ }^{13}$ Amir Mirzaie et al," A narrative literature review on traditional medicine options for treatment of corona virus disease 2019 (COVID-19)" Complementary Therapies In Clinical Practice. Vol 40 (2020), 101214.
} 


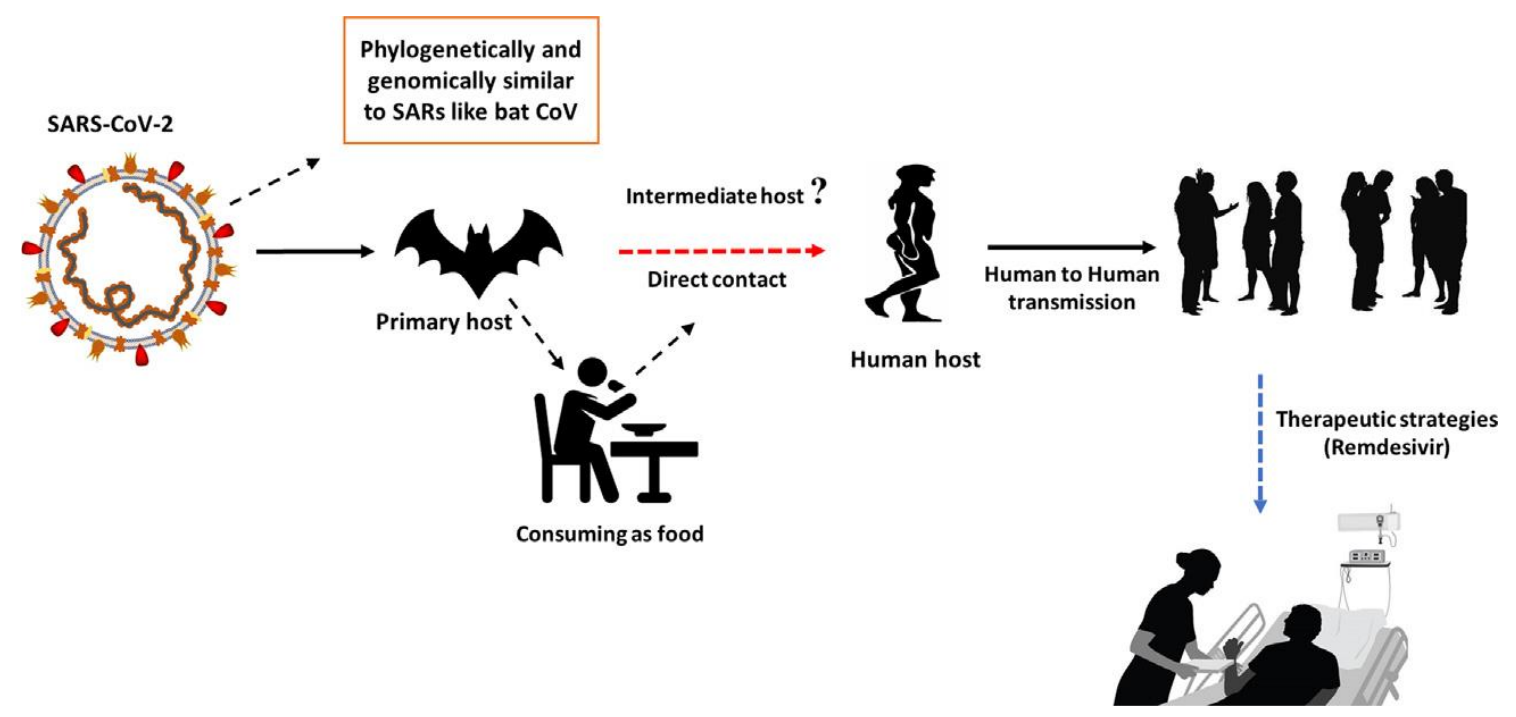

Gambar 3. Cara penularan virus corona manusia (Muhammad adnan shereen et al. 2020).

Sampai saat ini, belum ditemukan agen antivirus atau vaksin spesifik untuk infeksi COVID-19 dan hanya metode pengobatan yang mendukung serta bergejala. Prinsip umunya adalah menjaga hidrasi, kondisi nutrisi dan mengendalikan demam. ${ }^{14}$ Dari uraian di atas maka alternatif pencegahan penularan virus Corona adalah dengan melakukan PSBB.

\section{Homeschooling}

Di Indonesia konsep homeschooling sudah lama digunakan bahkan sebelum Indonesia merdeka. Tokoh sejarah KH. Agus Salim, Ki Hajar Dewantara, dan Buya Hamka telah berhasil mempraktikkan konsep homeschooling. ${ }^{15}$ Hanya saja dulu belum menggunakan istilah homeschooling. Istilah Homeschooling lahir di eropa sekitar tahun 1980-an. ${ }^{16}$ Homeschooling adalah pendidikan alternatif selain di sekolah yang terjangkau oleh semua kalangan, memberikan kemerdekaan dalam memilih model dan waktu pembelajaran yang cocok bagi anak. ${ }^{17}$ Menurut Carol (Griffith, 2008) didalam buku "Sekolah di Rumah: Memanfaatkan Seluruh Dunia Sebagai Ruang Kelas", pendidikan tanpa sekolah berarti mempelajari apa yang kita inginkan, saat kita menginginkannya, dengan cara yang kita inginkan, di tempat yang kita inginkan, untuk alasan kita sendiri. Pembelajaran menekankan dan memfokuskan pada anak, guru atau fasilitator dicari sesuai keinginan anak. Kebanyakan pembelajaran dilakukan dengan hening, bahkan tidak tampak, karena tidak ada fokus untuk menciptakan banyak "produk. ${ }^{18}$

\footnotetext{
${ }^{14}$ Amir, Ibid

${ }^{15}$ Achmad Razi, "Homeschooling: An Alternative Education In Indonesia," International journal of nusantara islam, no 04 (2016), 75-84

16 lbid.

${ }^{17}$ Rosalina Dewi Heryan," Homeschooling Sebagai Sekolah Alternatif Ramah Anak" Research and Develipment Journal of Education. No 3 (2017), 147

${ }^{18}$ Griffith, Mary, Sekolah Di Rumah:Memanfaatkan Seluruh Dunia Sebagai Ruang Kelas. (Bandung:Penerbit Nuansa, 2008.),17.
} 
Dari uraian di atas, dapat disimpulkan bahwa homeschooling dapat dijadikan alternatif pendidikan yang fleksibel sebagai substitute yang dapat menggantikan pendidikan jalur sekolah. hal ini dapat menjadi alternatif untuk semua kalangan di era pandemi COVID-19, dimana masyarakat tidak dapat mengikuti pendidikan jalur sekolah (formal). Konsep homeschooling adalah mengembalikan peran orang tua dan keluarga dalam pertumbuhan dan perkembangan anak. Dilihat dari ajaran islam, salah satu tanggung jawab orang tua terhadap anak adalah memberikan pendidikan bagi anak-anak. Abdullah bin Umar radhiallahu'anhuma berkata “ didiklah anakmu, karena sesungguhnya engkau akan diminta pertanggungjawaban mengenai pendidikan dan pengajaran yang telah engkau berikan padanya, dan dia juga akan ditanya mengenai kebaikan dirimu kepadanya serta ketaatannya kepada dirimu" (Tuhfah al maudud hal. 123). ${ }^{19}$ Dari sisi hukum homeschooling dilindungi oleh undang-undang no 20 tahun 2003 tentang sistem pendidikan nasional pada pasal 27 ayat (1) tertulis bahwa, " kegiatan pendidikan informal yang dilakukan oleh keluarga dan lingkungan berbentuk kegiatan belajar secara mandiri". Pada ayat (2) tertulis bahwa, " hasil pendidikan sebagaimana dimaksud dalam ayat (1) diakui sama dengan pendidikan formal dan nonformal setelah peserta didik lulus ujian sesuai dengan standar nasional pendidikan". ${ }^{20}$

Pendekatan yang digunakan dalam homeschooling yaitu proses pembelajaran memiliki rentang yang lebar antara yang sangat tidak terstruktur hingga sangat terstruktur seperti pembelajaran di sekolah. Beberapa model pembelajaran yang diterapkan dalam homeschooling antara lain : ${ }^{21}$

a) School at home adalah pendidikan seperti yang diselenggarakan di sekolah. Hanya saja, tempatnya tidak di seolah tatapi di rumah.metode ini sering di sebut textbook aproach, tradisional approach, atau school approach. ${ }^{22}$

b) Unit studies adalah model pendidikan yang berbasis pada tema. Dalam pendekatan ini sisiwa tidak belajar satu mata pelajran tertentu (Matematika, Bahasa, IPA, IPS), tetapi mempelajari banyak mata pelajaran sekaligus melalui sebuah tema yang dipelajarai. ${ }^{23}$

c) Charlotte Manson atau the living books adalah model pendidikan melalui pengalaman dunia nyata. Metode ini dikembangkan oleh Charlotte Manson. Pendekatan dilakukan dengan mengerjakan kebiasaan baik, keterampilan dasar (membaca, menulis, dan matematika) serta mengekspos anak dengan pengalaman nyata, seperti jalan-jalan mengunjungi museum, ke pasar, mencari informasi di perpustakaan dll. ${ }^{24}$

\footnotetext{
${ }^{19}$ Muhammad nur ichwan muslim, "Pendidikan Anak Tanggung Jawab Siapa" https://muslim.or.id/20835pemndidikan-anak-tanggung-jawab-siapa.html, di akses pada tanggal 2 juli 2020.

${ }^{20}$ Verdiansyah, Chris (ed), "Homeschooling; Rumah Kelasku, Dunia Sekolahku, (Jakarta: Penerbit Buku Kompas, 2007), 19

${ }^{21}$ Sumardiono. Homeschooling A Leap for Better Learning- Lompatan Cara Belajar, (Jakarta : PT. Elex Media Komputindo KELOMPOK GRAMEDIA, 2007) 21-23

${ }^{22}$ Xmulyono, https://xmulyono.wordpress.com/2008/05/28/tugas-3-riset-online-dari-ir-moh-adriyanto-msm/, di akses pada tanggal 1 juli 2020

23 lbid

${ }^{24} \mathrm{ibid}$
} 
d) The classical pendekatan ini menggunakan kurikulum yang distrukturkan berdasarkan tiga tahapan perkembangan anak yang disebut trivium. Penekanan metode ini adalah kemampuan ekspresi verbal dan tertulis. Pendekatanya berbasis teks atau literasi. ${ }^{25}$

e) The monstessori adalah model pendidikan yang dikembangkan oleh Dr. Maria montessori. Pendekatan ini mendorong penyiapan lingkungan pendukung yang nyata dan alami. Mengamati proses intraksi anak-anak di lingkungan, sehingga anak dapat mengembangkan potensinya, baik secara fisik, mental maupun spiritual. ${ }^{26}$

f) Unschooling adalah pendekatan yang berangkat dari keyakinan bahwa anak-anak memiliki keinginan natural untuk belajar. Jika keinginan itu difasilitasi dan dikenalkan dengan pengalaman di dunia nyata, mereka akan belajar lebih banyak daripada melalui metode lainnya. ${ }^{27}$

g) The eclectic adalah pendekatan yang memberikan kesempatan pada keluarga untuk mendesain sendiri program homeschooling yang sesuai, dengan memilih atau menggabungkan dari sistem yang ada. ${ }^{28}$

Seorang guru dan orang tua hanya mendampingi, membimbing serta memfasilitasi anak untuk belajar. Proses belajar sepenuhnya disesuikan dengan kebutuhan anak. pendekatanpendekatan di atas merupakan alternatif yang dapat dipilih oleh orang tua dalam menyelenggarakan homeschooling. Oleh karena itu, homeschooling dapat menciptakan suasana yang menyenangkan serta dapat membentuk anak yang kreatif dan mandiri.

Berdasarkan jenisnya, Homeschholing dibedakan menjadi tiga, yaitu homeschooling tunggal, homeschooling majemuk, dan komunitas homeschooling. Homeschooling tunggal adalah homeschooling yang dilaksanakan oleh orang tua dalam satu keluarga tanpa bergabung dengan yang lainnya. Alasan pemilihan homeschooling tunggal saat pandemi COVID-19 karena tidak memungkinkan berhubungan langsung dengan komunitas homeschooling lainnya. Pengajar homeschooling tunggal bisa orang tua atau memilih hoschooling tutorial sebagai alternatif saat pandemi COVID-19. Dimana orang tua memanggil guru mata pelajaran datang ke rumah. Dalam pelaksanaan homeschooling tunggal pemimpin (orang tua) dan tutor harus memiliki pengetahuan, kemampuan dan memahami tentang manajemen untuk keberhasilan suatu homeschooling ${ }^{29}$.

\section{Manajemen Pendidikan Islam}

Manajemen merupakan tindakan dalam menjalankan dan mengatur sebuah lembaga guna mencapai tujuan secara efektif dan efisien. manajemen diperlukan untuk mencapai tujuan yang telah ditentukan, terutama dalam tujuan pendidikan. Pendidikan nonformal tidak lepas

\footnotetext{
25 ibid

26 ibid

27 ibid

28 ibid

${ }^{29}$ Hsiao, H. C., et al, "Leadership of Vocational High School Principals in Curriculum Reform: A Case Study in Taiwan, "International Journal of Educational Development, vol 2, No 6,( 2008.) 669-686.
} 
dari maslah, homeschooling sebagai lembaga pendidikan nonformal harus dikelola dengan baik. Homeschooling tidak hanya sebagai pelengkap untuk berhasil dalam program pendidikan seumur hidup, tetapi juga sebagai pilihan alternatif selain pendidikan formal saat pandemi COVID-19. Untuk mewujudkan keberhasilan homeschooling, harus dilakukan kontrol dan manajemen pendidikan dengan baik. Manajemen pendidikan islam meliputi perencanaan, pengorganisasian, implementasi, evaluasi dan penghargaan.

a) Perencanaan (planning)merupakan langkah -langkah yang harus ditempuh untuk mencapai tujuan. Agar dalam melaksanakan homeschooling dapat berjalan dengan lacar dan dapat mencapai tujuan yang diharapkan, maka kegiatan yang harus dilakukan pada tahap awal adalah perencanaan, merencanakan tujuan yang ingin dicapai, siapa yang akan terlibat dalam pelaksaan homeschooling, merencanakan sarana dan prasarana yang dibutuhkan dan sebagainya. ${ }^{30}$

b) Pengaturan (Organizing) adalah sistem kerja sama sekelompok orang untuk mecapai tujuan bersama. Semua tugas dan kewajiban dalam homeschooling tidak diborong oleh satu orang, melainkan bekerja sama satu keluarga dan tutor yang dipercaya. Langkah pertama dalam pengorganisasian diwujudkan melalui perencanaan dengan menetapkan bidangbidang atau fungsi-fungsi yang termasuk ruang lingkup kegiatan yang akan diselenggarakan dalam melaksanakan homeschooling.

c) Evaluasi dalam kontek manajemen adalah proses untuk memastikan bahwa aktivitas yang dilaksanakan benar sesuai apa tidak dengan perencanaan yang telah ditentukan sebelumnya. Evaluasi dalam manajemen pendidikan islam mempunyai dua batasan yaitu: 1. Evaluasi proses/kegiatan untuk menentukan kemajuan pendidikan dibandingkan dengan tujuan yang telah ditentukan., 2. Evaluasi usaha untuk memperoleh informasi berupa umpan balik dari kegiatan yang telah dilakukan.

d) Penghargaan (reward) diberikan kepada kerja seseorang sehingga orang yang bekerja akan dihargai bahkan sebelum pekerja tersebut kering keringatnya, sebagai mana disebutkan dalam hadis Nabi Saw:

e) "Al-Abbas bin Walid al-Dimasyqiy telah menyampaikan (riwayat) kepada kami, Wahb bin Sa"id bin „Athiyyah al-Salamiy telah menyampaikan (riwayat) kepada kami, „Abd alRahman bin Zaid bin Aslam telah menyampaikan (riwayat) kepada kami, (riwayat itu) dari ayahnya, dari Abdullah bin Umar berkata, Rasulullah bersabda: Berikanlah gaji/upah pegawai sebelum kering keringatnya." (HR. Ibnu Majah). ${ }^{31}$

Manajemen pendidikan islam mangandung berbagai prinsip umum yang fleksibel sehingga bisa sejalan dengan kemajuan dan perkembangan zaman. Adapun prinsip teknis

\footnotetext{
${ }^{30}$ Endin Mujahidin et al, Perencanaan Pendidikan Konsep Jitu Mendirikan Sekolah Islam, (Bogor : Penerbit Program Pascasarjana UIKA Bogor, 2009), 6.

${ }^{31}$ Junaidi, "Prinsip-Prinsip Dasar Menejmen dalam Islam (Kajian Pendidikan Menurut Hadis Nabi), "Al-idarahjurnal Menejemen dan Administrasi Islam, No 1 (2017), 119-129.
} 
oprasional menejemen pendidikan islam yang dapat diterapkan dalam homeschooling sebagai berikut: $^{32}$

a) Ikhlas dalam menyusun perencanaan pendidik, pelaksana homeschooling harus tulus, integritas serta mendasarkan segala aktivitas yang dilakukan sebagai wujud ibadah. Prinsip ketulusan dalam manajemen pendidikan islam mampu menumbuhkembangkan budaya kepercayaan (trust), kejujuran (truthfulness), percaya diri (confidence) dan kerja sama (coperation). ${ }^{33}$

b) Jujur (sidq) yang dimaknai dengan keselarasan antara pikiran, perkataan, dan perbuatan baik yang sesuai dengan norma agama dan sosial. menejemen bisa efektif hanya apabila ia dilandasi oleh kejujuran, dengan kata lain kejujuran merupakan pusat terciptanya homeschooling yang efektif. ${ }^{34}$

c) Amanah (kepercayaan) prinsip bahwa dengan adanya kepercayaan homeschooling dapat terwujud dan dan mencapai tujuan yang diharapkan .

d) Adil semua keputusan yang diambil dalam perencanaan harus mencerminkan sikap adil, baik adil dalam menimbang, memutuskan , menyampaikan maupun dalam pelaksanaan

e) Tanggung jawab prinsip dimana semua tindakan yang dilakukan oleh seorang akan diminta pertanggung jawaban, bukan hanya dihadapan manusia tetapi juga dihadapan Allah SWT.

f) Dinamis prinsip perencanaan manajemen pendidikan islam senantiasa mengikuti perkembangan, tidak statsi dan selalu diarahkan kepada pencapaian tujuan pendidikan.

g) Praktis adalah kegiatan yang direncanakan harus selalu dapat diaplikasikan secara praktis , mudah diterima atau disampaikan

h) Musyawarah yakni prinsip dalam pengambilan keputusan harus dilandasi dengan mufakat dalam musnyawarah bersama.

\section{Metode Penelitian}

Kajian ini merupakan penelitian kualitatif (qualitative research) yang bertujuan untuk menggambarkan dan menganalisis fenomena-fenomena, peristiwa, aktivitas sosial, sikap, kepercayaan, persepsi, pemikiran orang secara individu ataupun kelompok. Penelitian ini terdapat upaya untuk mendeskripsikan, mencatat, menganalisis dan menginterpretasikan kondisi-kondisi yang saat ini terjadi. Penelitian ini hanya akan mendeskripsikan fenomena yang ada secara mendalam apa adanya, maka penelitian ini adalah penelitian deskriptif (descriptive research). Jenis penelitian deskriptif ini disebut juga penelitian praeksperimen karena dalam penelitian ini mereka melakukan eksplorasi dan menggambarkan fenomena

\footnotetext{
${ }^{32}$ Agus fakhruddin, "Prinsip-Prinsip Menejemen Pendidikan Islam dalam Konteks Persekolahan,"Jurnal Pendidikan Agama Islam, No 2 (2011), 207.

${ }^{33}$ Rini Rosdiana," Implementasi Prinsip-Prinsip Menejmen Pendidikan Islam: Studi Kasus Madrasah Ibtidaiyah" Al Mukminin" Kalangan, Jombang, “Jurnal Menejmen Pendidikan Islam, (2019), 80-101.

${ }^{34}$ Ibid
} 
Jurnal At Tadbir STAI Darul Kamal NW Kembang kerang NTB

Volume 5 No 1 Tahun 2021

P-ISSN : 2580-3433

E-ISSN : 2715-7210

https://journal.staidk.ac.id/index.php/tadbir

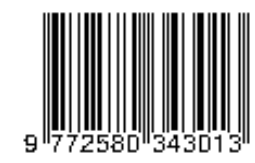

dengan tujuan untuk dapat menerangkan dan memprediksi terhadap sesuatu yang berlaku atas dasar data yang diperoleh di lapangan. Selain itu penelitian ini dilakukan dengan tujuan mengembangkan pengetahuan yang mendalam mengenai objek yang diteliti, sehingga sifat dari penelitian ini lebih banyak bersifat eksploratif dan deskriptif.

\section{Simpulan}

Dari uraian di atas dapat disumpulkan bahwa, tidak ada yang mengetahui kapan berakhirnya pandemi COVID-19. Bahkan saat ini jumlah kasus positif COVID-19 semakin bertambah jumlahnya, namun pendidikan harus terus berjalan. Homsechooling merupakan bentuk pendidikan alternatif yang bisa dipilih orang tua. Homeschooling merupakan pendidikan berbasis keluarga, orang tua, tutor bersama anak menentukan tujuan pembelajaran, metode, pendekatan, materi dan sumber belajar yang disesuaikan dengan strategi, kondisi dan gaya belajar. Dalam pelaksanaanya dibutuhkan suatu usaha, merencanakan, mengorganisir, mengevaluasi keberhasilan dari tujuan homeschooling. Hal tersebut diwujudkan dengan menerapkan prinsip-prinsip manajemen pendidikan islam.

\section{Daftar Rujukan}

Achmad Razi. 2016. Homeschooling: An Alternative Education In Indonesia. International journal of nusantara islam.

Agus fakhruddin. 2011. Prinsip-Prinsip Menejemen Pendidikan Islam dalam Konteks Persekolahan. Jurnal Pendidikan Agama Islam.

Amir Mirzaie, mehrded, farhad safarpoor dehkordi, reza ranjbar, hassan noorbaargan. 2020. A narrative literature review on traditional medicine options for treatment of

corona virus disease 2019 (COVID-19). Complementary Therapies In Clinical Practice. https://doi.org/10.1016/j.ctcp.2020.101214

Endin Mujahidin ,2009 .Perencanaan Pendidikan Konsep Jitu Mendirikan Sekolah Islam. Bogor : Penerbit Program Pascasarjana UIKA Bogor.

Global Health Journal. 2020. Diagnosis and Treatment Plan of Corona Virus Disease 2019(Tentativw Sixth Editian). Global Health Journal.

Griffith, Mary. 2008. Sekolah Di Rumah:Memanfaatkan Seluruh Dunia Sebagai Ruang Kelas. Bandung:Penerbit Nuansa.

Hsiao, H. C., Chen, M. N., Yang, H. Sen. 2008. Leadership of Vocational High School Principals in Curriculum Reform: A Case Study in Taiwan. International Journal of

Educational Development.

https://amp.kompas.com/regional/read/2020/03/24/15035821/update-kasus-pertama-1-warga$\underline{\text { ntb-positif-covid-19 }}$

https://prfmnews.pikiran-rakyat.com/nasional/pr-13391242/kemendikbud-terbitkan-pedomanbelajar-dari-rumah-di-masa-darurat-covid-19

https://www.jogloabang.com/kesehatan/pp-21-2020-pembatasan-sosial-berskala-besar-

rangka-percepatan-penanganan-covid-19 
Jurnal At Tadbir STAI Darul Kamal NW Kembang kerang NTB

Volume 5 No 1 Tahun 2021

P-ISSN : 2580-3433

E-ISSN : 2715-7210

https://journal.staidk.ac.id/index.php/tadbir

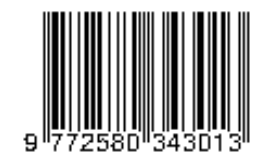

Junaidi. 2017. Prinsip-Prinsip Dasar Menejmen dalam Islam (Kajian Pendidikan Menurut Hadis Nabi). Al-idarah- jurnal Menejemen dan Administrasi Islam.

Muhammad adnan shereen, suliman khan, abeer kazmi, nadia bashir, rabeea siddique. 2020. Covid-19 infection: origin, transmission, and characteristics of human coronavirus. Journal of advanced research. https://doi.org/10.1016/j.jare.2020.03.005 Muhammad nur ichwan muslim, "Pendidikan Anak Tanggung Jawab Siapa" https://muslim.or.id/20835-pemndidikan-anak-tanggung-jawab-siapa.html

Renan C. Castillo,Elena D. Staguhn, Elias Weston-farber.2020. The Effect of State-Level Stay- At-Home Orders on Covid-19 Infection Rates. AJIC: American Journal of

Infection Control.doi: https://doi.org/10.1016/j.ajic.2020.05.017

Rini Rosdiana. 2019. Implementasi Prinsip-Prinsip Menejmen Pendidikan Islam: Studi Kasus Madrasah Ibtidaiyah” Al Mukminin” Kalangan, Jombang. Jurnal Menejmen Pendidikan Islam.

Rosalina Dewi Heryan. 2017. Homeschooling Sebagai Sekolah Alternatif Ramah Anak. Research and Develipment Journal of Education.

Siti Aminah, hasil wawancara virtual MTs. An-nasriyah. Kedatu lombok timur, 4 Juli 2020

Soalihin, hasil wawancara virtual SMPN 1 Lamboya Barat, Kedatuk Lombok Timur, 1 Juli 2020

Sumardiono. 2007. Homeschooling A Leap for Better Learning- Lompatan Cara Belajar. Jakarta : PT. Elex Media Komputindo KELOMPOK GRAMEDIA.

úllker Devrim, Nuri Bayram. 2020. nfection Control Practices in Children During Covid- 19 Pandemic: Differences From Adults. Ajic: American Journal of Infection Control.doi: https://doi.org/10.1016/j.ajic.2020.05.022

Verdiansyah, Chris (ed). 2007. Homeschooling; Rumah Kelasku, Dunia Sekolahku. Jakarta: Penerbit Buku Kompas.

Xmulyono, https://xmulyono.wordpress.com/2008/05/28/tugas-3-riset-online-dari-ir-mohadriyanto- $\mathrm{msm} /$, di akses pada tanggal 1 Juli 2020 